\title{
The beef tenderness model
}

\author{
L. Frylinck ${ }^{1 \#}$, A. O'Neil ${ }^{2}$, E. du Toit ${ }^{2}$, P.E. Strydom ${ }^{1}$ \& E.C. Webb ${ }^{2}$ \\ ${ }^{1}$ Department of Meat Science, Agricultural Research Council - Animal Production Institute, \\ Private Bag X2, Irene, 0062, South Africa \\ ${ }^{2}$ Department of Animal and Wildlife Sciences, University of Pretoria, Private Bag X20, Hatfield, \\ Pretoria 0028, South Africa
}

(Received 25 November 2014; Accepted 7 April 2015; First published online 29 July 2015)

\author{
Copyright resides with the authors in terms of the Creative Commons Attribution 2.5 South African Licence. \\ See: http://creativecommons.org/licenses/by/2.5/za \\ Condition of use: The user may copy, distribute, transmit and adapt the work, but must recognise the authors and the South African \\ Journal of Animal Science.
}

\begin{abstract}
In Phase 1 of this study, three breed types (Simmentaler-, Brahman- and Nguni bulls; $\mathrm{n}=60$ each) were grain-fed and slaughtered at 12 months of age (A-age, fat-class 2). Feed was withdrawn for either three hours or 24 hours pre-slaughter. Within each feed withdrawal group, three electrical stimulation (ES) treatments were applied, viz. ES for 15 seconds, 120 seconds or no stimulation. In Phase 2, the effects of animal age and feeding regime were investigated using of A-age (feedlot and pasture), AB-age (feedlot and pasture) and B-age (pasture) animals. All carcasses were electrically stimulated for 15 seconds. Longer feed withdrawal increased dark-firm-dry (DFD) meat occurrence $(\mathrm{pHu}>6$ ) in the Nguni and Simmentalercross. Brahman-cross longissimus (LL) tended to be more tender with paler colour and higher drip loss when 120 ES was applied. Longer feed withdrawal recorded higher Warner Bratzler shear force (WBSF) than three hour feed withdrawal. However, ES neutralized the effect of stress on tenderness. On average the AB-age feedlot animals produced the most tender LL followed by the B-age pasture and A-age feedlot which was similar to the $A B$-age pasture. A-age pasture animals produced the least tender LL steaks. The calpain proteolytic system played a pivotal role in determining the ultimate meat tenderness and although connective tissue becomes less soluble in older animals it did not play the determinant role in tenderness in this study. The intramuscular fat $(<3 \%)$ played an important role in the tenderness outcome of Nguni LL which marbled well at $A B$-age.
\end{abstract}

Keywords: Meat tenderness, $\mathrm{pH}$ and temperature decline profile, pre- and post-slaughter conditions, production systems

${ }^{\#}$ Corresponding author: Lorinda@arc.agric.za

\section{Introduction}

According to various international consumer surveys, and irrespective of the animal species, the most important sensory quality attributes of meat are tenderness followed by juiciness and flavour (Ouali, 1991; Koohmaraie, 1992; Warkup et al., 1995). From the producers' point of view, much money is at stake in supplying consistent eating quality of meat products to the market and therefore, the accurate prediction of meat tenderness is very important. Age of bovine animals has been used in South Africa since 1936 as a characteristic to grade carcasses, presumably because carcasses of younger cattle were considered to be of "better" quality than those of older cattle (Government Notice No. 1548 of 1936).

The concept of meat tenderness is very complex and is biologically dependent on a combination of many physiological factors (Ouali, 1990):

- Proteolytic degradation of cytoskeletal proteins primarily by the calcium activated calpain system (Koohmaraie, 1992, Dransfield, 1999) and related to myofibre fragment length (MFL).

- Muscle contraction dependent on muscle energy at slaughter and related to sarcomere length (SL) (Goll et al., 1997).

- Intra-muscular connective tissue (IMCT) characteristics represented by total collagen and collagen solubility - covalent cross-links and composition profiles vary between muscles within one animal, within a single muscle, with animal age, nutrition and growth rate, as well as breed (Purslow, 1999). IMCT accounts for about $20 \%$ of the variation in tenderness according to Dransfield (1995).

- Marbling and fat profile accounts for less than $10 \%$ of variation in longissimus tenderness, according to Dransfield (1995). 
Information on the status of these mechanisms at a given time and under a specific combination of situations could provide scientific information that can be used to build a model to explain differences and develop technologies to manipulate and standardise meat tenderness and the tenderising process.

The three critical time periods when meat tenderness can be affected are immediately pre-slaughter, during slaughter and immediately post-slaughter (Dransfield, 1995). Many pre-slaughter factors may induce stress and deplete muscle glycogen. Some of these factors are the duration and manner of animal transportation from the farm to the abattoir, diet restrictions and genetic factors. If glycogen is depleted the extent of post mortem acidification is reduced (ultimate $\mathrm{pH}>6.0$ ) leading to the production of dark-firm-dry (DFD) meat. This meat is then prone to spoilage and has poor sensory qualities. The capacity of muscle to recover from glycogen exhaustion is very slow particularly in beef and conditions causing glycogen depletion should be carefully managed. Even limited stress, i.e. stress that does not necessarily result in DFD meat, could impair meat quality $(\mathrm{pH}>5.8)$. Muscle with a final $\mathrm{pH}$ between 5.8 and 6.2 is often not so dark, but its ageing capacity has been impaired (Schaefer et al., 1997).

Under South African conditions the variations in pre-slaughter conditions and abattoir operations influencing the glycolytic pathways are expected to be very large. To some extent this is the result of deregulation, more role-players (often inexperienced) participating in the supply chain and the fact that many of the processes between the feedlot and abattoir are still not well established, e.g. time of feed withdrawal prior to slaughter (Strydom et al., 2009). Dr Gerhard Neethling, manager of the South African Red Meat Abattoir Association (RMAA) and Mr Dave Ford, Executive Director of the South African Feedlot Association (SAFA), suggested that the most common pre-slaughter treatments in South Africa are:

- Feed withdrawal about a day before slaughter and transportation of at least $50 \mathrm{~km}$ to abattoir. Offload, rest overnight at abattoir (foreign place) and slaughter early the next day.

- $\quad$ Feed withdrawal 2 to 3 hours before slaughter - feed withdrawal just before transport (early in the morning). Transportation of at least $50 \mathrm{~km}$ to abattoir (about 2 hours). Offload, rest 1.5 - 2 hours and slaughter within three hours after arrival at abattoir.

Electrical stimulation increases the rate of post mortem metabolism and prevents cold by hastening the depletion of ATP (energy) in the muscle and subsequently the onset of rigor, ensuring that full rigor is attained before muscles chill to below $10^{\circ} \mathrm{C}$. A threshold of $10^{\circ} \mathrm{C}$ whilst ATP levels are still sufficiently high, has been set for cold shortening (Bendall, 1972). Under certain conditions such as high voltage electrical stimulation, it causes mechanical disruption of cytoskeletal proteins in post mortem muscle, thus improving tenderness in another way (Ho et al., 1996). Unfortunately the water holding capacity of the muscle can be negatively affected if electrical stimulation conditions are not properly controlled, e.g. over stimulation can cause the loss of juiciness and tougher meat (Strydom et al., 2000, Frylinck \& Heinze, 2003). It may be necessary to implement a much shorter electrical stimulation period than is currently the norm in commercial abattoirs, namely 15 seconds, as compared to 2 minutes at $500 \mathrm{~V}$ (Thompson, 2002).

From previous studies (Frylinck \& Heinze, 2003) it became clear that different breeds react differently to specific post-slaughter treatment combinations. It is well documented that tenderness decreases as the percentage Bos indicus increases in a crossbred animal (Crouse et al., 1989; Whipple et al., 1990; De Bruyn, 1991; Shackelford et al., 1995; Koohmaraie, 1996). It has been shown that these differences (between Bos indicus and Bos taurus) occur due to differences in the properties of calpain/calpastatin activity and their subsequent effects on the myofibrillar properties of the muscle. One of the most advantageous aspects of electrical stimulation is that breed differences in tenderness of the $m$. longissimus are reduced (Ferguson et al., 2000; Frylinck, 2001).

The most common breed-types being used in South African feedlots are Brahman $(\mathrm{Br}-\mathrm{X})$ - and Simmentaler (Sm-X) - crosses and represent Bos indicus and Bos taurus types respectively. Nguni (Ng) was used to represent the indigenous Sanga breed-type.

A research project funded by the South African Meat Board and was carried out by scientists of the Meat Industry Centre (MIC) at ARC-Irene in the early 1990s showed that meat tenderness decreased as the slaughter age of the animals increased, in the order of 0-, 2-, 4-, 6- and 8-incisors. Samples of meat from 0 -incisor animals were significantly more tender than those of the 2-incisor animals. The 2-, 4- and 6-incisor animals were not appreciably different in terms of tenderness. Fat content did not affect the tenderness results (Crosley et al., 1994). In spite of these results that confirmed the accuracy of the current Classification System, some meat producers still denied their validity and exerted pressure on the authorities to eventually classify the carcasses of 2-incisor animals in a separate age class (AB) then the 3- to 6-incisor animals (B) and 0-incisor animals (A) (Government Notice No. R.342 of 1999). Based on the believe that younger animals produce more tender meat, the largest percentages of beef carcasses in South Africa are derived from 0-incisor cattle (A-age class - predominantly from feedlots). Modern feedlot technologies and economics drive beef production toward larger framed, more rapidly growing, implanted cattle, with the help of feed additives ( $\beta$-agonists) so that the animals can be harvested at a younger age. All these factors 
influence meat tenderness negatively (Owens \& Gardner, 1999; Strydom et al., 2009). Beef animals raised on natural grazing to the same fatness have often just cut their first permanent incisor(s) when slaughtered (AB-age class) and due to a general lower selling price per kilogram for AB-age - than for A-age class carcasses, equal weight carcasses of the A-age class yield higher returns than those of the other age classes (Anon, 2000).

In Phase 2 of this project five different production systems were tested; A-age (feedlot and pasture)-, AB-age (feedlot and pasture)-, and B-age (pasture) beef cross-breeds. Young bulls were used in Phase 1, but because Phase 2 tests were done over a three year time period, older bulls could influence tenderness results because of high testosterone levels, only steers were used.

The objectives were to develop a model from which the ideal pre- and post-slaughter procedures could be derived; to compare the inherent meat tenderness (shear force measurements) of South African breedtypes under typical South African commercial abattoir practices (chilling at $4^{\circ} \mathrm{C}$ within 2 hours post-stunning) (Phase 1) and to evaluate the meat tenderness and calpain system differences of A-age (feedlot and pasture) animals, AB-age (feedlot and pasture) animals, and B-age (pasture) animals under the determined ideal slaughter conditions for South African crossbred beef breeds (Phase 2).

\section{Materials and Methods}

Model building input 1 (Phase 1): One hundred and eighty animals of three breed-types typically processed in South African feedlots were studied, Bos indicus represented by Brahman crosses (Br-X; $n=$ $60 \pm 486 \mathrm{~kg}$ ), Sanga type represented by Nguni ( $\mathrm{Ng} ; \mathrm{n}=60 \pm 363 \mathrm{~kg}$ ) and European Bos taurus represented by Simmentaler crosses $(\mathrm{Sm}-\mathrm{X} ; \mathrm{n}=60 \pm 480 \mathrm{~kg}$ ) were used. The animals were fed on a feedlot diet for a period of between 90 - 110 days at the ARC-API feedlot and slaughtered at A-age, fatness class 2 at the ARC-abattoir. Pre-slaughter treatments were: feed withdrawal about 24 hours before slaughter (FW24; $n=$ 90) and transportation for at least $50 \mathrm{~km}$ to abattoir, then offloaded, rested overnight at the abattoir (foreign place) and slaughtered early the next day; and feed withdrawal 3 hours before slaughter (FW3; $n=90$ ), (feed withdrawal just before transport early in the morning), transportation for at least $50 \mathrm{~km}$ to abattoir (about 2 hours), then offloaded, rested 1.5 - 2 hours and slaughtered within 3 hours after arrival at abattoir. Postslaughter treatments were; 120 seconds electrical stimulation, $400 \mathrm{~V}$ peak, 5 ms pulses, 15 pulses per second (the traditional procedure) (ES120; $n=60), 15 \mathrm{sec}$ electrical stimulation, $400 \mathrm{~V}$ peak, 5 ms pulses, 15 pulses per sec $(E S 15 ; n=60)$ and non-electrical stimulation $(N S ; n=60)$. All carcasses were placed into the chiller at $4^{\circ} \mathrm{C}$ within 1 hour after slaughter. The effect of ageing on meat characteristics were tested 1 day, 7 days and 14 days post mortem.

Model building input 2 (Phase 2): One hundred and fifty animals of three breed-types typically processed in the South African feedlots were studied, Bos indicus (Br-X;n=50), Sanga type $(\mathrm{Ng}) ; n=50)$, and European Bos taurus (Sm-X; $n=50$ ) were used. Five production systems were tested: AF - average for the animals reared at the feedlot until A-age, ABF - average for the animals reared at the feedlot until ABage, $A P$ - average for the animals reared on the pasture until A-age, ABP - average for the animals reared on the pasture until $A B$-age, $B P$ - average for the animals reared on the pasture until $B$-age. The pasture animals were raised on the ARC-Roodeplaat. Experimental Farm (2067 ha) situated in the Gauteng Province, South Africa approximately $30 \mathrm{~km}$ north-east of Pretoria, between the southern latitudes $25^{\circ} 20^{\prime}$ and $25^{\circ} 40^{\prime}$ and the eastern longitudes $28^{\circ} 17^{\prime}$ and $28^{\circ} 25^{\prime}$ which receives an annual precipitation of between 380 and $700 \mathrm{~mm}$. The average daily maximum and minimum temperature for this region is $32^{\circ} \mathrm{C}$ and $18^{\circ} \mathrm{C}$ in January and $22{ }^{\circ} \mathrm{C}$ and $4^{\circ} \mathrm{C}$ in July (AGROMET, 1994). The vegetation in this area is described as Savanna (Rutherford \& Westfall, 1994), and as Sourish Mixed Bush pasture (Pasture Type 19) (Acocks, 1988). Except for the grazing the animals also received summer lick (200 kg Ca ${ }^{2+}$ phosphate/ton; $300 \mathrm{~kg}$ salt/ton; $50 \mathrm{~kg}$ urea/ton; $450 \mathrm{~kg}$ maize meal/ton) and winter lick (150 kg mono calcium phosphate/ton; $250 \mathrm{~kg}$ salt/ton; $150 \mathrm{~kg}$ urea/ton; $450 \mathrm{~kg}$ maize meal/ton) supplementation. The feedlot animals were raised in a feedlot situated on the experimental farm of the Agricultural Research Council - Animal Production Institute, Irene, South Africa. A standard type of high concentrate diet was supplied to the feedlot animals (12 MJ/kg DM, $135 \mathrm{~g}$ protein $/ \mathrm{kg}$ ) for a period of 90 - 110 days which included a 14 day adaption period. Normal animal husbandry practices were applied. All the animals were weighed every two weeks, and during summer the pasture animals received a weekly treatment against ticks. For comparative purposes the same nonaggressive growth promoter (Ralgro; $36 \mathrm{mg}$ zeranol; Schering-Plough, South Africa) was implanted at the beginning of the finishing period. This research was approved by the ARC-API Ethics Committee (ref no. APIEC11/025).

Feed was withdrawn three hours pre-slaughter and the carcasses were electrically stimulated for 15 seconds (400 V peak, 5 ms pulses at 15 pulses per sec). The carcasses were placed in the chiller at $4{ }^{\circ} \mathrm{C}$ within 1 hour. The effect of ageing on meat characteristics was tested 1 day, 7 days and 14 days post mortem. Temperature and $\mathrm{pH}$ decline profiles were measured at the last lumbar vertebra of the 
m. longissimus lumborum (LL) of the left side in all carcasses early post mortem and at 24 hours post mortem to monitor and diagnose dark firm and dry (DFD) and pale, soft and exudative (PSE) phenomena.

The $L L$ of both right and left sides were removed from the third last rib to the last lumbar vertebra and sub-sampled for Warner-Brazier shear force (WBS) and sensory analyses in the case of Phase 2, sarcomere length (SL), myofibril fragmentation (MFL) and calpain system (calpain-I, calpain-II and calpastatin). The position of sampling for each test was consistent; the different samples were either frozen immediately at $-20^{\circ} \mathrm{C}$ or snap frozen in liquid nitrogen and stored at $-80{ }^{\circ} \mathrm{C}$ or vacuum packed and aged $\left(2 \pm 2{ }^{\circ} \mathrm{C}\right)$ for 7 and 14 days post-slaughter. Sarcomere length was measured on a fresh sample.

For Warner-Bratzler shear force measurements and sensory analyses where applicable, 1 day postslaughter (un-aged), 7 and 14 days aged frozen LL cuts were processed into $30 \mathrm{~mm}$ steaks by means of a band saw before being thawed at $4{ }^{\circ} \mathrm{C}$ for 24 hours, and prepared according to an oven-broiling method using direct radiant heat (AMSA, 1995). The steaks were broiled at $200^{\circ} \mathrm{C}$ (pre-set) to $70{ }^{\circ} \mathrm{C}$ internal temperature. Each cooked steak was allowed to cool for $10 \mathrm{~min}$, cut into $1.5 \times 1.5 \mathrm{~cm}$ squares and then wrapped in tin foil for sensory analyses. Sensory evaluation was done by a trained sensory panel consisting of 10 members (Sensory Analytical Laboratory, Meat Industry Centre, Agricultural Research Council, Animal Production Institute) that assessed tenderness, first bite, amount of residue (connective tissue), flavour, juiciness and sustainable juiciness on an 8 point scale. A score of 8 described the sample as extremely intense in aroma and flavour, extremely juicy, extremely tender with no connective tissue residue, while a score of 1 describe it as extremely bland in aroma and flavour intensity, extremely dry, extremely tough with extremely abundant connective tissue residue (AMSA, 1995). For WBS measurements the steaks were kept intact and left at room temperature $\left( \pm 22^{\circ} \mathrm{C}\right)$ before coring. Eight cylindrical samples with a core diameter of $12.5 \mathrm{~mm}$ were removed parallel to the grain of the meat and sheared perpendicular to fibre direction using a Warner-Bratzler shear device mounted on an Instron Universal Testing Machine, Model 4301, Series IX Automated Materials Testing System Version 5 (Instron, 1990). Shear force was measured as the peak force $(\mathrm{kg})$ average for eight cores per sample. The WBS of each steak was measured as the maximum force required to shear a cylindrical core cooked steak perpendicular to the grain, at a cross head speed of 400 $\mathrm{mm}$ per second.

The sarcomere lengths (SL) were measured on fresh samples taken at 1 and 3 days post mortem using a Video Image Analyser (Kontron, Germany) according to the method of Hegarty \& Naudé (1970), using distilled water instead of Ringer Locke solution (Dreyer et al., 1979).

The myofibril fragment lengths (MFL) were measured in LL samples of meat aged for 1, 7 and 14 days post mortem homogenised with a blunt blade. MFL were measured by means of a Video Image Analyser (Kontron, Germany). The extraction procedure was performed according to the method of Culler et al. (1978) as modified by Heinze \& Bruggemann (1994).

Calpastatin in combination with calpain-I and calpain-II was extracted from $5 \mathrm{~g}$ of the LL frozen samples as described by Dransfield (1996) and separated by means of the two-step gradient ion-exchange chromatography-method of Geesink \& Koohmaraie (1999). Calpain-I activity in eluates containing both calpainI and calpastatin (which are not easily separated) is estimated from calpastatin measurements before and after heating of the eluates. Calpain assays were performed using azo-casein as substrate according to Dransfield (1996). The use of azo-casein eliminates the problem of background absorbance of non-specific proteins in the extracts. One unit of calpain activity is defined as an increase in absorbance at $366 \mathrm{~nm}$ of 1.0 per hour at $25^{\circ} \mathrm{C}$. One unit of calpastatin activity was defined as the amount that inhibited one unit of calpain-II activity. Data were expressed as units per gram of muscle or units per milligram of extractable protein (specific activity). Protein concentration of the LL frozen samples was determined by the Buiret method of Cornall et al. (1949).

Total collagen content (total hydroxy-proline nitrogen content) in the $\mathrm{m}$. longissimus muscle was determined by determining the hydroxy-proline content in hydrolised samples according to Bergman \& Loxley (1963). The solubility of the intramuscular collagen (hydroxy-proline nitrogen content of soluble collagen) was determined according to the method of Hill (1966) with some modifications. Freeze dried meat samples (1 g) were pulverised and added to $12 \mathrm{~mL}$ of a $1 \% \mathrm{NaCl}$ solution. The samples were heated in a water bath for 60 minutes at $78^{\circ} \mathrm{C}$. After centrifugation and removal of the supernatant, the supernatant was hydrolysed by adding $30 \mathrm{~mL} 6 \mathrm{~N} \mathrm{HCl}$ and heated for 16 hours at $110^{\circ} \mathrm{C}$. Active carbon was added to the hydrolised samples which were then filtered and diluted with distilled water to $100 \mathrm{~mL}$. Hydroxy-proline was colorimetrically determined by neutralising the acid in the samples with $10 \% \mathrm{KOH}$, and then oxidising the hydroxyproline with Chloramine-T for 20 minutes. Ehrlich's reagent was then added and the samples were placed in a water bath of 15 minutes at $60{ }^{\circ} \mathrm{C}$. The absorbance of the pink colour was measured at $558 \mathrm{~nm}$ in a $1 \mathrm{~cm}^{3} \mathrm{cuvette}$ as described by Bergman \& Loxley (1963). All determinations were performed in triplicate. Collagen solubility was calculated by expressing hydroxy-proline in the filtrate as a percentage of the total hydroxy-proline of the filtrate plus residue. Collagen content was calculated as hydroxy-proline nitrogen per total protein nitrogen (Hypro $\mathrm{N} x$ $10^{3}$ /total protein $\mathrm{N}$ ) by calculating hydroxy-proline nitrogen from hydroxy-proline MM 131.13 and nitrogen atom 
number 14.0067. Collagen values were expressed as $\mathrm{mg}$ collagen/g of sample by using the hydroxy-proline conversion of 7.25 and 7.53 for insoluble and soluble collagen, respectively (Cross et al., 1973).

Percentage (\%) intramuscular fat (IMF) which is related to marbling, was determined chemically (fat, ash, protein moisture) by using methods of the Association of Official Analytical Chemists (AOAC; 1985).

The data of WBS, sensory analyses (where applicable) and MFL, were subjected to analysis of variance for a split plot design (GenStat, 2003) with the three breed types (Br-X, Ng, Sm-X) as whole plots and the three ageing periods (1, 7 and 14 days post mortem) as sub-plots. Means for the interactions between sub-plot and whole-plot were separated using Fisher's protected t-test least significant difference (LSD) at the $1 \%$ and $5 \%$ levels of probability (Snedecor \& Cochran, 1980). Sources of variance for the rest of the data collected (SL; calpain-I and calpain-II activity and calpastatin activity; total collagen and percentage collagen solubility; percentage intramuscular fat) involving in breed effects were investigated by one-way ANOVA.

\section{Results and Discussion}

Effects of pre- and post-slaughter conditions and production system on $\mathrm{pH}$ and temperature decline profiles and consequences for muscle contraction (cold shortening and heat shortening)

The $\mathrm{pH} /$ temperature window concept as implemented by the Meat Standards Australia (MSA) grading scheme to monitor or identify carcasses in danger of cold shortening $\left(\mathrm{pH}>6\right.$ at $\left.\mathrm{T}<10{ }^{\circ} \mathrm{C}\right)$ or heat toughening ( $\mathrm{pH}<6$ at $\mathrm{T}>35^{\circ} \mathrm{C}$ ) (Thompson, 2002) was used. The temperature/pH decline profiles of Phase 1 carcasses presented in Figure 1A show that although non-stimulated carcasses risk being cold shortened, in this study on average these carcasses did not fall into the high risk cold shortening window. This could be because the experimental chillers may not be as effective as normal commercial chillers. Heat shortening in the ES-120 carcasses posed a greater risk as their results fell into the heat shortening window, which could lead to less tender meat and high drip loss. The ideal post-slaughter procedure was identified as ES-15 electrical stimulation where $\mathrm{pH}$ decline was controlled (not too rapidly) by applying electrical stimulation for a short period. When studying the temperature/pH decline profiles of Phase 2 carcasses presented in Figure 1B it is evident that electrical stimulation for a short period (15 seconds.) none of the carcasses was exposed to the risk of cold or heat shortening.

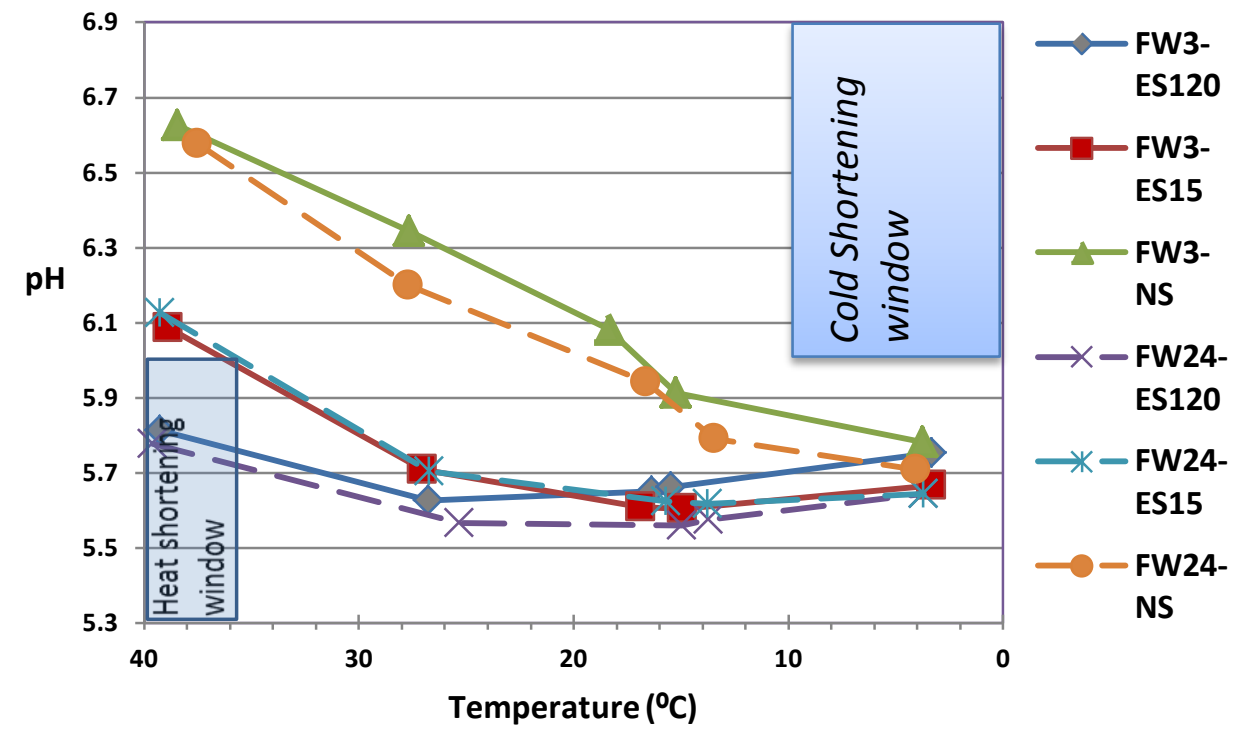

Figure 1A Temperature and $\mathrm{pH}$ decline profiles as measured in carcasses of Phase 1 pre- and postslaughter treatments: FW3-ES120 (feed withdrawal 3 hours before slaughter, 120 seconds electrical stimulation post slaughter), FW3-ES15 (feed withdrawal 3 hours before slaughter, 15 sec electrical stimulation post slaughter); FW3-NS (feed withdrawal 3 hours before slaughter, non-electrical stimulation post slaughter); FW24-ES120 (feed withdrawal 24 hours before slaughter, 120 seconds electrical stimulation); FW24-ES15 (feed withdrawal 24 hours before slaughter, $15 \mathrm{sec}$ electrical stimulation); FW24NS (feed withdrawal 24 hours before slaughter, non-electrical stimulation). Cold shortening and heat shortening windows according to Pearson \& Young (1989) and as discussed by Thompson (2002). 


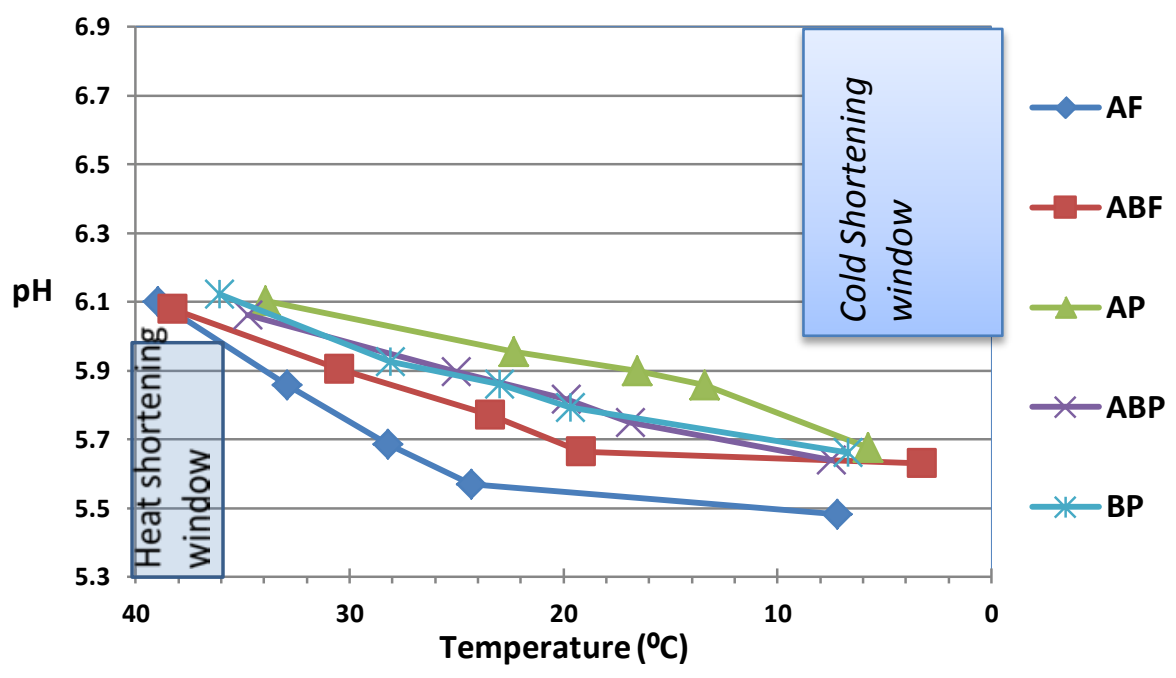

Figure 1B Temperature and $\mathrm{pH}$ decline profiles as measured in carcasses of Phase 2; production systems; $A F$ (the animals reared at the feedlot until A-age), ABF (animals reared at the feedlot until AB-age), AP (animals reared on the pasture until A-age), ABP (animals reared on the pasture until AB-age) and $B P$ (animals reared on the pasture until B-age). Cold shortening and heat shortening windows according to Pearson \& Young (1989) and as discussed by Thompson (2002).

Sarcomere lengths are an indication of contraction protein characteristics, which are an indication of the energy status of the muscle. Electrical stimulation has a significant effect on sarcomere length which seems to be detrimental to the tenderising processes if over stimulated (120 seconds, Table 1$)$. The SLs of $\mathrm{Br}-\mathrm{X}$ and $\mathrm{Sm}-\mathrm{X}$ were longer $(P<0.049)$ than the SLs of $\mathrm{Ng}$ carcasses (Table 1$)$. SLs of Br-X and Sm-X were similar or slightly shorter than in previous studies involving the same breeds under the same production and slaughter conditions. Strydom et al. (2000), Frylinck (2001), Frylinck \& Heinze (2003) and Strydom et al. (2008) reported SLs ranging from 1.71 to $1.77 \mu \mathrm{m}$ for $\mathrm{Br}-\mathrm{X}$ and 1.66 to $1.71 \mu \mathrm{m}$ for Sm-X. On the other hand, the $\mathrm{Ng}$ tended to have longer SL under controlled slower chilling conditions $(1.83 \mu \mathrm{m})$ or when electrically stimulated $(1.75-1.89 \mu \mathrm{m})$. Although the average results for AP carcasses did not fall within the cold

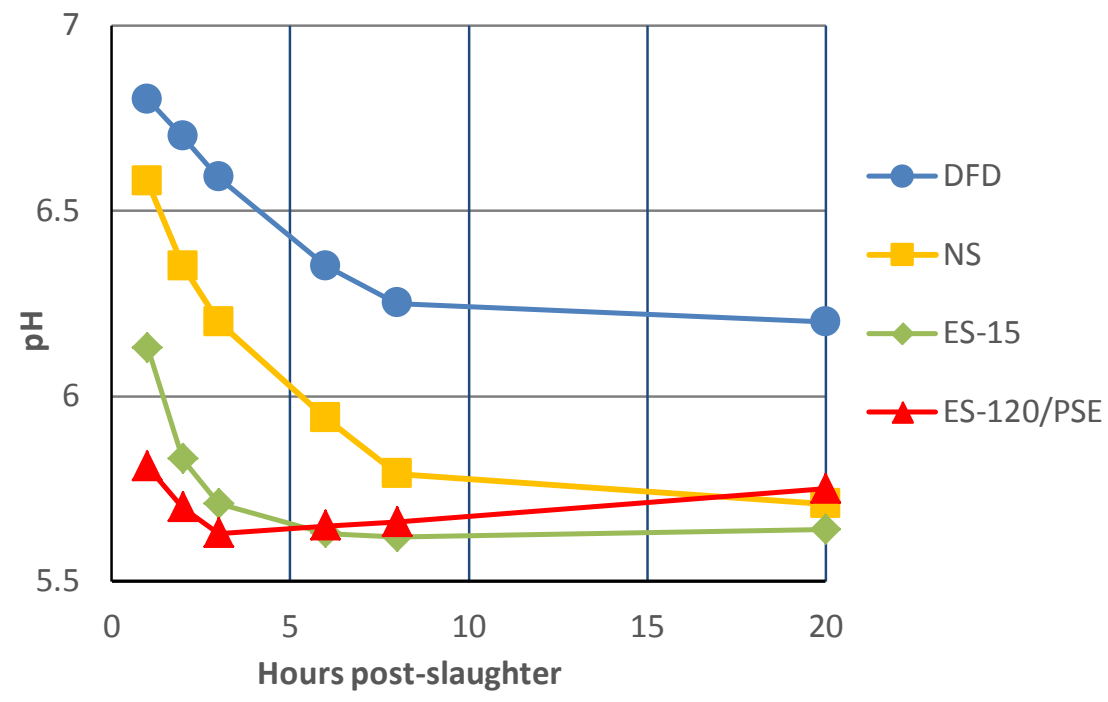

Figure 2 Typical pH decline profiles found in early post mortem carcasses; Dark firm and dry (DFD) - pH of carcass stays above 5.9 - low initial muscle energy (FW-24); normal non-electrical stimulated carcasses (NS); electrically stimulated for $15 \mathrm{sec}(400 \mathrm{~V}$ peak, $5 \mathrm{~ms}$ pulses at 15 pulses per sec) (ES-15); electrically stimulated for $120 \mathrm{sec}$ ( $400 \mathrm{~V}$ peak, $5 \mathrm{~ms}$ pulses at 15 pulses per sec) (ES-120) - lead to pale, soft and exudative (PSE) phenomena (high drip loss and low water holding capacity). 
shortening window it is possible that individual carcasses or even individual muscle fibres within the carcasses could have been subjected to cold shortening. AP loins recorded shorter sarcomere lengths (SL; $1.66 \mu \mathrm{m})$ than those from the AF, ABF, ABP and BP systems $(\sim 1.75 \mu \mathrm{m})(P<0.05$; Table 5).

The contraction characteristics of the ABF group were the most relaxed because the sarcomere lengths measured at 1 day post mortem in the ABF group were significantly longer than in the other treatment groups. The AP treatment group was the most contracted and the sarcomere lengths were the shortest of all (Table 5) - an indication of a high energy state.

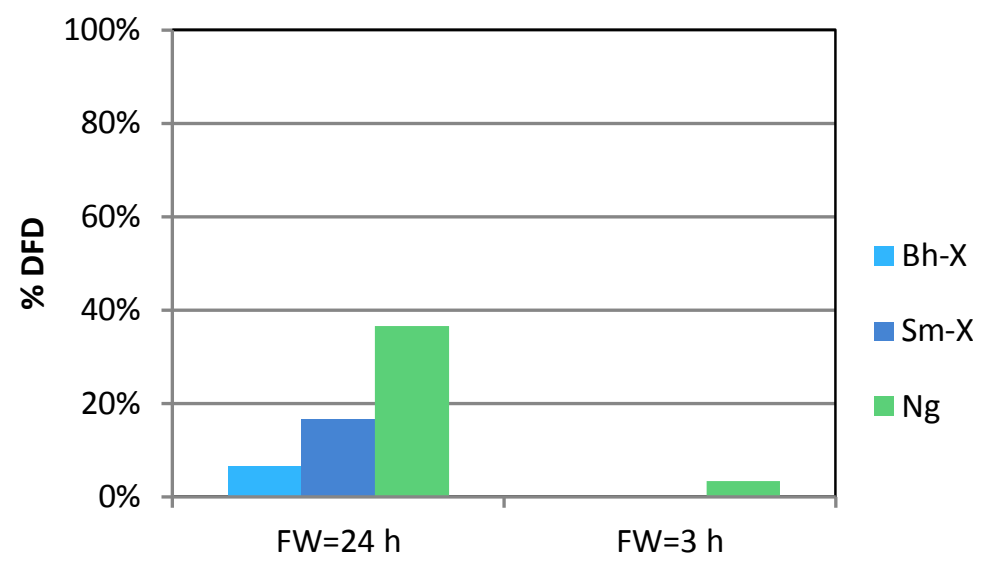

Pre-slaughter feed withdrawal period

Figure 3 Incidence of dark firm and dry (DFD; pH $24 \geq 5.9$ ) after two feed withdrawal periods, 24 hours preslaughter (FW-24) and 3 hours pre-slaughter (FW-3); $n=180$ animals.

Breed: Bh-X = Brahman crosses; Sm-X = Simmentaler crosses; Ng = Nguni.

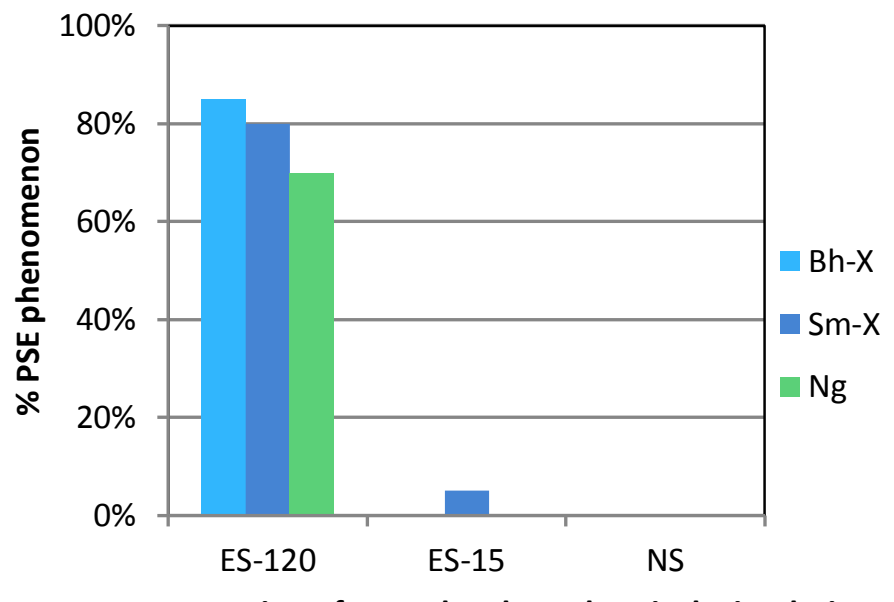

Figure 4 Incidence of pale, soft and exudative (PSE) like phenomenon in carcasses stimulated for 120 seconds (ES-120), 15 seconds (ES-15) and no stimulation (NS).

Breed: Bh-X = Brahman crosses; Sm-X = Simmentaler crosses; Ng = Nguni.

Monitoring temperature and $\mathrm{pH}$ decline early post mortem is useful to enable the diagnosis of pale, soft and exudative (PSE) like or dark, firm and dry (DFD) phenomena and overall energy status of the animal at slaughter. Figure 2 shows typical $\mathrm{pH}$ decline profiles found in post-slaughter carcasses. Dark firm and dry (DFD) phenomena when the $\mathrm{pH}$ of the carcass stays above 5.9, occur when the initial muscle energy postslaughter is low. The frequency of DFD was the highest in the FW-24 treatment group as reflected in Figure 3. FW-3 had minimal incidence of DFD, only a small number of Nguni carcasses showed DFD, indicating that if the energy of the muscle just before slaughter can be controlled this phenomenon can to a great extent be prevented. The incidence of a PSE-like phenomenon was extremely high in the ES-120 postslaughter treatment group. This phenomenon was rare in the ES-15 group and in the NS group (Figure 4). 
PSE-like phenomenon was not encountered in Phase 2 because the post-slaughter procedure was standardised to the short ES (15 seconds). Not many DFD phenomena were encountered in Phase 2 except for the $\mathrm{Ng}$ that had on average a slightly higher post rigor $\mathrm{pH}$ as measured after 24 hours post mortem ( $\mathrm{pHu}$ 5.7) in the AP group. This indicates that the Nguni had a tendency to DFD in the AP production group. The $\mathrm{pHu}$ of 5.5 of the AF production group was significantly lower than that of the other groups $(\mathrm{pHu}=5.65)$,

Table 1 The effect of breed-type, feed withdrawal period and electrical stimulation on meat tenderness related physiological characteristics measured in the $m$. longissimus (LL)

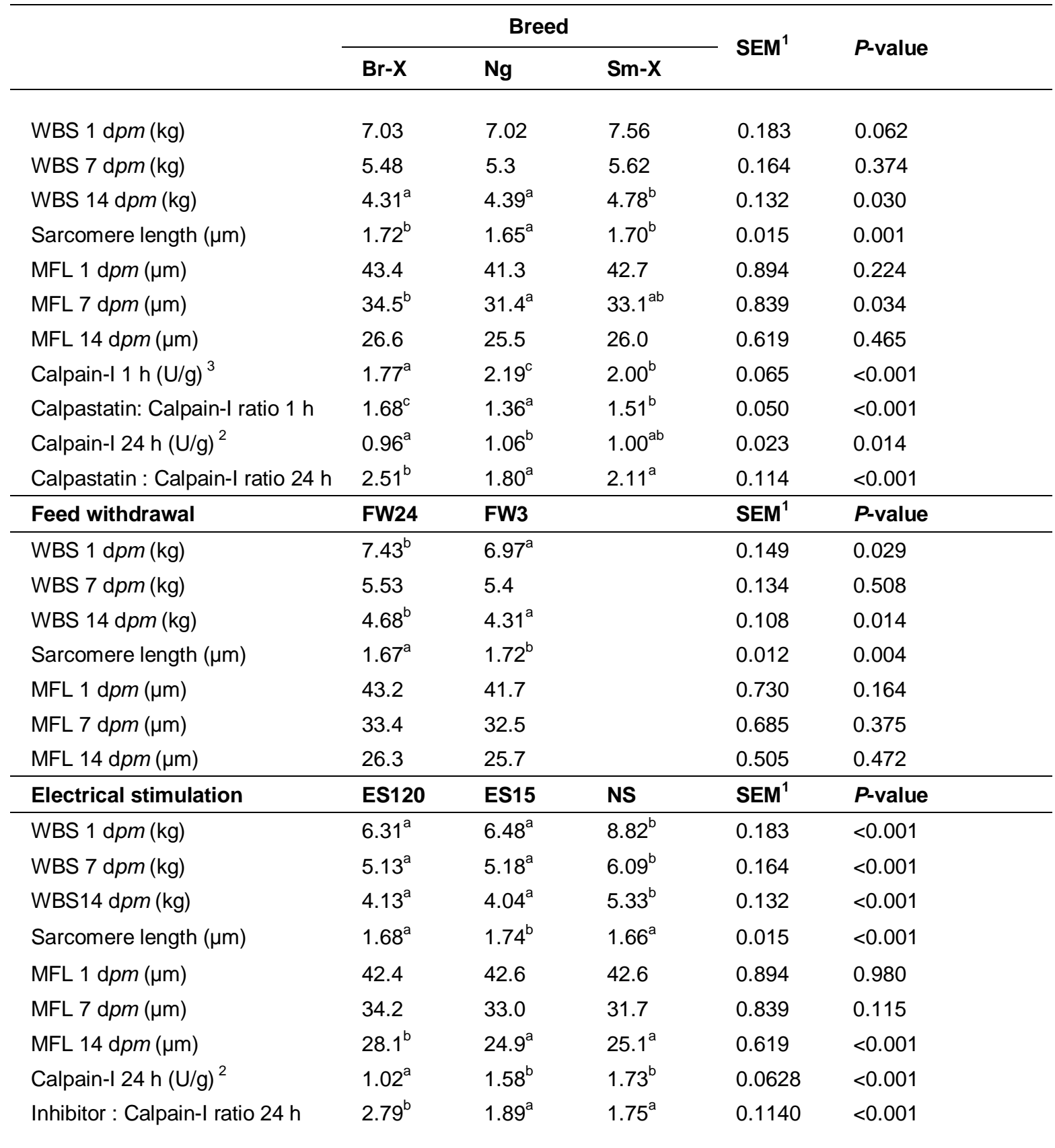

$a, b, c$ Means within a row with different superscripts differ significantly $(P<0.05) .{ }^{1}$ Standard error of means.

${ }^{2}$ Calpain enzyme activity was expressed in units per gram of muscle.

dpm: days post mortem; WBS: Warner Bratzler shear force; MFL: myofibril fragment length.

Breed: $\mathrm{Br}-\mathrm{X}=$ Brahman crosses; $\mathrm{Ng}=$ Nguni; $\mathrm{Sm}-\mathrm{X}=$ Simmentaler crosses;

Feed withdrawal: FW24: feed withdrawal $24 \mathrm{~h}$ before slaughter; FW3: feed withdrawal $3 \mathrm{~h}$ before slaughter.

Electrical stimulation: ES120: 120 seconds electrical stimulation; ES15: 15 sec electrical stimulation; NS: non-electrical stimulation. 
which seems to indicate that the AF production group has an advantage above the other groups in this regard.

\section{Effect of pre- and post-slaughter conditions and production system on tenderness mechanisms}

To understand the processes that effect meat tenderness, it was important to study the mechanisms involved with meat tenderness and tenderisation. The effects of breed-type, feed withdrawal period and electrical stimulation on 1 day, 7 days and 14 days post mortem Warner Bratzler shear force values are represented in Table 1. Significant shear force differences between breeds were only apparent after 14 days post mortem where Sm-X tended to be a bit tougher than the other breed-types. Feed withdrawal period had an effect on shear force at day 1 and 14 days post-slaughter (FW3 more tender than FW14), showing longer sarcomere length at FW3 a bit more relaxed $(1.72 \mu \mathrm{m})$ than that of FW24 $(1.67 \mu \mathrm{m})$. Electrical stimulation enhanced the tenderness (lower WBS) in both ES treatments but is just as effective at 15 seconds, without

Table 2 Influence of production system on Warner Bratzler shear force and production system and breedtype on sensory quality attributes measured in $m$. longissimus (LL) at day 1,7 and 14 days post mortem

\begin{tabular}{|c|c|c|c|c|c|c|c|}
\hline & \multicolumn{5}{|c|}{ Production systems } & \multirow{2}{*}{$\mathrm{SEM}^{1}$} & \multirow{2}{*}{$P$-value } \\
\hline & AF & AP & ABF & ABP & BP & & \\
\hline \multicolumn{8}{|c|}{ Warner Bratzler shear force } \\
\hline $1 \mathrm{dpm}$ & $6.57^{\mathrm{ab}}$ & $7.61^{\mathrm{c}}$ & $6.04^{\mathrm{a}}$ & $6.95^{\mathrm{b}}$ & $6.20^{\mathrm{a}}$ & 0.231 & $<0.001$ \\
\hline $7 \mathrm{dpm}$. & $5.30^{\mathrm{ab}}$ & $5.72^{\mathrm{b}}$ & $4.83^{\mathrm{a}}$ & $5.51^{b}$ & $4.99^{\mathrm{a}}$ & 0.199 & 0.011 \\
\hline $14 \mathrm{dpm}$ & $4.22^{\mathrm{ab}}$ & $4.70^{c}$ & $3.87^{\mathrm{a}}$ & $4.60^{\mathrm{bc}}$ & $3.88^{\mathrm{a}}$ & 0.148 & $<0.001$ \\
\hline \multicolumn{8}{|c|}{ Sensory analyses by 10 member trained panel: } \\
\hline \multicolumn{8}{|c|}{ First bite $^{2}$} \\
\hline $1 \mathrm{dpm}$ & $4.86^{c}$ & $3.46^{\mathrm{a}}$ & $4.83^{c}$ & $3.97^{\mathrm{b}}$ & $4.23^{\mathrm{b}}$ & 0.154 & $<0.001$ \\
\hline $7 \mathrm{dpm}$ & $5.83^{\mathrm{C}}$ & $4.85^{\mathrm{a}}$ & $5.87^{\mathrm{c}}$ & $4.78^{\mathrm{a}}$ & $5.32^{\mathrm{b}}$ & 0.148 & $<0.001$ \\
\hline $14 \mathrm{dpm}$ & $6.33^{\mathrm{c}}$ & $5.16^{\mathrm{a}}$ & $6.34^{\mathrm{c}}$ & $5.46^{\mathrm{b}}$ & $5.53^{\mathrm{ab}}$ & 0.133 & $<0.001$ \\
\hline \multicolumn{8}{|c|}{ Tenderness $^{3}$} \\
\hline $1 \mathrm{dpm}$ & $4.97^{\mathrm{C}}$ & $3.67^{\mathrm{a}}$ & $4.99^{c}$ & $4.03^{\mathrm{ab}}$ & $4.44^{\mathrm{b}}$ & 0.152 & $<0.001$ \\
\hline $\mathrm{Br}-\mathrm{X}$ & 4.70 & 3.99 & 4.82 & 4.07 & 4.05 & 0.263 & 0.054 \\
\hline Sm-X & 5.37 & 3.88 & 4.85 & 4.18 & 4.41 & & \\
\hline $\mathrm{Ng}$ & 4.83 & 3.14 & 5.31 & 3.83 & 4.85 & & \\
\hline $7 \mathrm{dpm}$ & $5.85^{\mathrm{c}}$ & $5.05^{\mathrm{ab}}$ & $5.89^{c}$ & $4.92^{\mathrm{a}}$ & $5.42^{\mathrm{b}}$ & 0.143 & $<0.001$ \\
\hline $\mathrm{Br}-\mathrm{X}$ & 5.47 & 5.03 & 5.53 & 4.84 & 5.42 & 0.248 & 0.118 \\
\hline Sm-X & 6.23 & 5.53 & 5.90 & 4.79 & 5.59 & & \\
\hline $\mathrm{Ng}$ & 5.84 & 4.58 & 6.23 & 5.14 & 5.26 & & \\
\hline $14 \mathrm{dpm}$. & $6.38^{\mathrm{c}}$ & $5.33^{\mathrm{a}}$ & $6.41^{\mathrm{c}}$ & $5.65^{\mathrm{ab}}$ & $5.74^{\mathrm{b}}$ & 0.120 & $<0.001$ \\
\hline $\mathrm{Br}-\mathrm{X}$ & $6.13^{\mathrm{c}}$ & $5.42^{\mathrm{b}}$ & $6.26^{c}$ & $5.51^{b}$ & $5.76^{\mathrm{b}}$ & 0.209 & 0.027 \\
\hline Sm-X & $6.71^{d}$ & $5.91^{\mathrm{bc}}$ & $6.44^{\mathrm{cd}}$ & $5.62^{\mathrm{b}}$ & $5.78^{\mathrm{b}}$ & & \\
\hline $\mathrm{Ng}$ & $6.31^{\mathrm{c}}$ & $4.66^{\mathrm{a}}$ & $6.52^{d}$ & $5.81^{b}$ & $5.69^{b}$ & & \\
\hline \multicolumn{8}{|c|}{ Residue $^{4}$} \\
\hline $1 \mathrm{dpm}$ & $4.76^{c}$ & $3.61^{\mathrm{a}}$ & $4.81^{\mathrm{c}}$ & $3.94^{\mathrm{ab}}$ & $4.35^{\mathrm{b}}$ & 0.136 & $<0.001$ \\
\hline $7 \mathrm{dpm}$ & 5.62 & 4.85 & 5.62 & 4.84 & 5.27 & 0.137 & $<0.001$ \\
\hline $14 \mathrm{dpm}$. & $6.10^{\mathrm{b}}$ & $5.22^{\mathrm{a}}$ & $6.13^{\mathrm{b}}$ & $5.45^{\mathrm{a}}$ & $5.53^{\mathrm{a}}$ & 0.111 & $<0.001$ \\
\hline
\end{tabular}

$\overline{a, b, c, d}$ Means in a row with different superscripts differ significantly $(P<0.05)$ with the Fisher's means separation test. dpm: days post mortem.

${ }^{1}$ Standard error of means. ${ }^{2}$ First bite $\left(1=\right.$ extremely tough; to $8=$ extremely tender). ${ }^{3}$ Tenderness $(1=$ extremely tough; to $8=$ extremely tender). ${ }^{4}$ Residue $(1=$ extremely abundant; to $8=$ none $)$.

AF: animals reared in feedlot until A-age; $A B F$ : animals reared in feedlot until AB-age; $A P$ : animals reared on pasture until A-age; ABP: animals reared on pasture until AB-age; BP: animals reared on pasture until $B$-age. 
the detrimental PSE effects of 120 seconds (Figure 4). Shorter sarcomere lengths detected for the Ngunitypes (Table 1) indicate that this breed-type can be prone to muscle shortening, probably because of its higher muscle energy status and small frame characteristics (carcasses cool too rapidly). On the other hand the Nguni-crosses seem to have more advantageous proteinase characteristics shown in the shorter myofibril fragment lengths (MFL) measured at 7 days post-slaughter, higher calpain-I levels and lower calpastatin/calpain-I levels (Table 1).

Electrical stimulation has a significant effect on sarcomere length and myofibre fragment length (MFL), which seems to be detrimental to the tenderising processes if overstimulated (120 seconds, Table 1$)$. While the proteinase characteristics are similar in 15 seconds ES and none-electrical stimulated meat, these characteristics were detrimentally affected in 120 seconds ES meat.

For Phase 2 a significant breed effect was detected for sensory tenderness measurements with the Sm-X now producing the most tender meat overall (Table 2) as would have been expected from a Taurus breed (Shackelford et al., 1995). The muscle contraction characteristics of the ABF group were the most relaxed because the sarcomere lengths measured in the ABF group were significantly longer than in the other treatment groups, with the AP treatment group the most contracted with the shortest sarcomere lengths (Table3) - which is an indication of a high energy state. The $\mathrm{Ng}$ also seems to have a higher energy state in the muscle as reflected by their shorter sarcomere lengths compared to the other breed-types (Table 3).

Table 3 The influence of age-feed regime and cross-breed on meat tenderness related physiological characteristics measured in the $m$. longissimus (LL)

\begin{tabular}{|c|c|c|c|c|c|c|c|}
\hline & \multicolumn{5}{|c|}{ Production systems } & \multirow{2}{*}{ SEM $^{1}$} & \multirow{2}{*}{$P$-value } \\
\hline & $\mathrm{AF}$ & AP & $A B F$ & $A B P$ & BP & & \\
\hline \multicolumn{8}{|c|}{ Sarcomere length $(\mathrm{SL})(\mu \mathrm{m})$} \\
\hline $1 \mathrm{dpm}$ & $1.74^{\mathrm{b}}$ & $1.66^{\mathrm{a}}$ & $1.76^{\mathrm{b}}$ & $1.73^{\mathrm{b}}$ & $1.73^{\mathrm{b}}$ & 0.014 & $<0.001$ \\
\hline \multicolumn{8}{|c|}{ Myofibre fragment length (MFL) $(\mu \mathrm{m}):$} \\
\hline $1 \mathrm{dpm}$ & $40.77^{\mathrm{C}}$ & $39.62^{\mathrm{C}}$ & $36.38^{\mathrm{ab}}$ & $38.74^{\mathrm{bc}}$ & $35.19^{\mathrm{a}}$ & 1.083 & 0.002 \\
\hline $\mathrm{Br}-\mathrm{X}$ & 42.21 & 42.04 & 41.75 & 39.88 & 38.19 & 1.876 & 0.218 \\
\hline $\mathrm{Sm}-\mathrm{X}$ & 37.55 & 38.75 & 34.45 & 35.29 & 33.03 & & \\
\hline $\mathrm{Ng}$ & 42.56 & 38.07 & 32.95 & 41.04 & 34.37 & & \\
\hline $7 \mathrm{dpm}$ & $32.97^{\mathrm{b}}$ & $31.29^{\mathrm{b}}$ & $31.36^{\mathrm{b}}$ & $32.05^{\mathrm{b}}$ & $29.30^{\mathrm{a}}$ & 0.672 & 0.004 \\
\hline $\mathrm{Br}-\mathrm{X}$ & $35.30^{\mathrm{ef}}$ & $32.50^{d}$ & $37.98^{f}$ & $35.30^{\mathrm{ef}}$ & $30.64^{\mathrm{cd}}$ & 1.164 & $<0.001$ \\
\hline Sm-X & $30.00^{\mathrm{bc}}$ & $29.15^{b}$ & $29.07^{b}$ & $28.19^{\mathrm{a}}$ & $28.20^{a b}$ & & \\
\hline $\mathrm{Ng}$ & $33.61^{\mathrm{de}}$ & $32.23^{d}$ & $27.03^{\mathrm{a}}$ & $32.66^{\mathrm{d}}$ & $29.06^{b}$ & & \\
\hline $14 \mathrm{dpm}$ & $26.74^{\mathrm{a}}$ & $27.24^{\mathrm{ab}}$ & $26.45^{\mathrm{a}}$ & $28.41^{\mathrm{b}}$ & $25.68^{\mathrm{a}}$ & 0.574 & 0.017 \\
\hline $\mathrm{Br}-\mathrm{X}$ & 27.88 & 26.89 & 27.94 & 28.74 & 25.38 & 0.995 & 0.238 \\
\hline Sm-X & 25.17 & 26.26 & 26.30 & 26.43 & 24.95 & & \\
\hline $\mathrm{Ng}$ & 27.17 & 28.58 & 25.10 & 30.06 & 26.71 & & \\
\hline \multicolumn{8}{|c|}{ Collagen characteristics } \\
\hline $\begin{array}{l}\text { Soluble } \\
\text { collagen }(\mathrm{mg} / \mathrm{g})\end{array}$ & $0.197^{\mathrm{ab}}$ & $0.262^{c}$ & $0.219^{b}$ & $0.213^{\mathrm{b}}$ & $0.167^{\mathrm{a}}$ & 0.015 & $<0.001$ \\
\hline $\begin{array}{l}\text { Insoluble } \\
\text { collagen }(\mathrm{mg} / \mathrm{g})\end{array}$ & $1.255^{\mathrm{a}}$ & $1.837^{\mathrm{c}}$ & $1.574^{b}$ & $1.794^{\mathrm{c}}$ & $1.689^{\mathrm{bc}}$ & 0.061 & $<0.001$ \\
\hline $\begin{array}{l}\text { Total collagen } \\
(\mathrm{mg} / \mathrm{g})\end{array}$ & $1.452^{\mathrm{a}}$ & $2.098^{d}$ & $1.802^{\mathrm{b}}$ & $2.007^{\mathrm{cd}}$ & $1.855^{\mathrm{bc}}$ & 0.072 & $<0.001$ \\
\hline $\begin{array}{l}\text { Collagen } \\
\text { solubility (\%) }\end{array}$ & $13.46^{\mathrm{d}}$ & $12.18^{\mathrm{c}}$ & $11.31^{\mathrm{bc}}$ & $10.58^{\mathrm{b}}$ & $8.98^{\mathrm{a}}$ & 0.408 & $<0.001$ \\
\hline $\begin{array}{l}\text { \% intra } \\
\text { muscular fat }\end{array}$ & $1.94^{c}$ & $0.84^{a}$ & $2.33^{d}$ & $1.06^{a}$ & $1.58^{b}$ & 0.10 & $<0.001$ \\
\hline
\end{tabular}

${ }_{\mathrm{a}, \mathrm{b}, \mathrm{c}, \mathrm{d}, \mathrm{e}, \mathrm{f}}$ Means within a row with different superscripts differ significantly $(P<0.05) ;{ }^{1}$ Standard error of means. dpm: days post mortem.

$A F$ : animals reared in feedlot until $A$-age; $A B F$ : animals reared in feedlot until $A B$-age; $A P$ : animals reared on pasture until A-age; $A B P$ : animals reared on pasture until $A B$-age; $B P$ : animals reared on pasture until $B$-age. 
ABF was the most tender (lowest WBS), although still similar in tenderness compared to the AF and AP treatment groups (Table 2). On the other hand AP was significantly tougher than the other treatment groups and ABP was similar to both AP and AF (Table 2). On an age-feed level, calpastatin at 1 hour and 24 hours post-slaughter was the highest in the feedlot animals compared to the pasture animals (Table 4) and BP (older animals) had the lowest level of extractable calpastatin at both 1 hour and 24 hours post mortem followed by the ABP and AP production systems. On the other hand the calpain-I levels were the highest at 1 hour and 24 hours post-slaughter in the ABF group, which can cancel out the negative effect of calpastatin. This is reflected in the lower calpastatin/calpain-I ratio of this age-feed group. ABF and BP had the same and lowest calpastatin/calpain-I ratio compared to AF, AP and ABP. This can be an explanation why ABF and BF productions systems produced the most tender meat (Table 4). It seems that the calpain system might be benefitted by age of the animal. This might be explained by the phenomenon of sarcopenia which increases with age of the animal or in this case human (Faulkner et al., 2007). According to the split-plot the BP and ABF treatment groups had the shortest and similar myofibre fragment lenghts, followed by the ABP and the $A F$ and AP groups the longest (Table 3). On the production system level the genetic expression of the calpain system also seemed to play a very important role in relation to the ultimate tenderness of the meat. Calpain substrate degradation and product formation correspond with the calpain system outcomes mentioned.

Table 4 Influence of production system on the different components of the calpain system at 1 hour and 24 hours post mortem measured in the $m$. longissimus (LL)

\begin{tabular}{|c|c|c|c|c|c|c|c|}
\hline & \multicolumn{5}{|c|}{ Production systems } & \multirow{2}{*}{ SEM $^{1}$} & \multirow{2}{*}{$P$-value } \\
\hline & AF & AP & ABF & ABP & BP & & \\
\hline \multicolumn{8}{|c|}{ Calpastatin (U/g) } \\
\hline $1 \mathrm{hpm}$ & $2.38^{\mathrm{c}}$ & $2.20^{\mathrm{ab}}$ & $2.37^{c}$ & $2.23^{b}$ & $2.09^{\mathrm{a}}$ & 0.046 & $<0.001$ \\
\hline $24 \mathrm{hpm}$ & $1.92^{\mathrm{C}}$ & $1.66^{\mathrm{b}}$ & $2.04^{c}$ & $1.62^{b}$ & $1.45^{\mathrm{a}}$ & 0.053 & $<0.001$ \\
\hline \multicolumn{8}{|c|}{ Spesific calpastatin (U) } \\
\hline $1 \mathrm{hpm}$ & $0.040^{\mathrm{b}}$ & $0.041^{\mathrm{b}}$ & $0.041^{b}$ & $0.040^{b}$ & $0.035^{\mathrm{a}}$ & 0.001 & $<0.001$ \\
\hline $24 \mathrm{hpm}$ & $0.036^{\mathrm{cd}}$ & $0.033^{b c}$ & $0.038^{d}$ & $0.032^{b}$ & $0.027^{\mathrm{a}}$ & 0.001 & $<0.001$ \\
\hline \multicolumn{8}{|c|}{ Calpain-I (U/g) } \\
\hline $1 \mathrm{hpm}$. & $1.18^{b}$ & $1.05^{\mathrm{a}}$ & $1.31^{c}$ & $1.10^{\mathrm{ab}}$ & $1.15^{\mathrm{b}}$ & 0.033 & $<0.001$ \\
\hline $24 \mathrm{hpm}$ & $0.76^{\mathrm{a}}$ & $0.74^{\mathrm{a}}$ & $0.93^{b}$ & $0.70^{\mathrm{a}}$ & $0.67^{\mathrm{a}}$ & 0.037 & $<0.001$ \\
\hline \multicolumn{8}{|c|}{ Spesific calpain-I (U) } \\
\hline $1 \mathrm{hpm}$ & $0.020^{\mathrm{a}}$ & $0.019^{a}$ & $0.023^{b}$ & $0.020^{\mathrm{a}}$ & $0.019^{\mathrm{a}}$ & 0.001 & $<0.001$ \\
\hline $24 \mathrm{hpm}$ & $0.014^{a}$ & $0.015^{\mathrm{ab}}$ & $0.017^{b}$ & $0.014^{a}$ & $0.013^{\mathrm{a}}$ & 0.001 & $<0.001$ \\
\hline \multicolumn{8}{|c|}{ m-Calpain (U/g) } \\
\hline $1 \mathrm{hpm}$ & $1.05^{\mathrm{cd}}$ & $0.94^{\mathrm{a}}$ & $1.09^{d}$ & $0.98^{\mathrm{ab}}$ & $1.01^{\mathrm{bc}}$ & 0.020 & $<0.001$ \\
\hline $24 \mathrm{hpm}$. & $0.91^{\mathrm{a}}$ & $0.93^{\mathrm{a}}$ & $1.12^{\mathrm{C}}$ & $0.94^{\mathrm{a}}$ & $1.00^{\mathrm{b}}$ & 0.018 & $<0.001$ \\
\hline \multicolumn{8}{|c|}{ Spesific m-Calpain (U) } \\
\hline $1 \mathrm{hpm}$ & $0.018^{\mathrm{ab}}$ & $0.017^{\mathrm{a}}$ & $0.019^{b}$ & $0.018^{\mathrm{ab}}$ & $0.017^{\mathrm{a}}$ & 0.0003 & 0.008 \\
\hline $24 \mathrm{hpm}$ & $0.017^{\mathrm{a}}$ & $0.019^{b}$ & $0.021^{c}$ & $0.019^{b}$ & $0.018^{a b}$ & 0.0003 & $<0.001$ \\
\hline \multicolumn{8}{|c|}{ Calpastatin/calpain-I } \\
\hline $1 \mathrm{hpm}$. & $2.07^{b}$ & $2.19^{b}$ & $1.85^{\mathrm{a}}$ & $2.06^{b}$ & $1.85^{\mathrm{a}}$ & 0.055 & $<0.001$ \\
\hline $24 \mathrm{hpm}$ & 2.66 & 2.34 & 2.32 & 2.45 & 2.33 & 0.101 & 0.098 \\
\hline \multicolumn{8}{|c|}{ Calpastatin/calpain-II } \\
\hline $1 \mathrm{hpm}$ & $1.07^{\mathrm{b}}$ & $1.13^{\mathrm{b}}$ & $1.00^{\mathrm{a}}$ & $1.08^{\mathrm{b}}$ & $0.97^{\mathrm{a}}$ & 0.022 & $<0.001$ \\
\hline $24 \mathrm{hpm}$ & $1.16^{\mathrm{c}}$ & $1.00^{b}$ & $1.01^{b}$ & $0.99^{b}$ & $0.89^{\mathrm{a}}$ & 0.029 & $<0.001$ \\
\hline
\end{tabular}

$\overline{\mathrm{a}, \mathrm{b}, \mathrm{c}, \mathrm{d}}$ Means within a row with different superscripts differ significantly $(P<0.05)$; ${ }^{1}$ Standard error of means. hpm: hours post mortem.

$A F$ : animals reared in feedlot until $A$-age; $A B F$ : animals reared in feedlot until $A B$-age; $A P$ : animals reared on pasture until A-age; ABP: animals reared on pasture until AB-age; BP: animals reared on pasture until $B$-age. 
Table 5 The influence of breed-type on the different components of the calpain proteolytic system at 1 hour and 24 hours post mortem and other tenderness related physiological characteristics measured in the m. longissimus (LL)

\begin{tabular}{|c|c|c|c|c|c|}
\hline & \multicolumn{3}{|c|}{ Cross-breeds } & \multirow{2}{*}{ SEM } & \multirow{2}{*}{$P$-value } \\
\hline & $\mathrm{Br}-\mathrm{X}$ & Sm-X & $\mathrm{Ng}$ & & \\
\hline \multicolumn{6}{|c|}{ Calpastatin (U/g) : Breed-type average } \\
\hline $1 \mathrm{hpm}$ & $2.343^{b}$ & $2.166^{\mathrm{a}}$ & $2.250^{\mathrm{b}}$ & 0.036 & 0.003 \\
\hline $24 \mathrm{hpm}$ & $1.89^{\mathrm{b}}$ & $1.65^{a}$ & $1.69^{\mathrm{a}}$ & 0.041 & $<0.001$ \\
\hline \multicolumn{6}{|c|}{ Spesific Calpastatin (U) : Breed-type average } \\
\hline $1 \mathrm{hpm}$ & $0.041^{\mathrm{b}}$ & $0.038^{\mathrm{a}}$ & $0.039^{\mathrm{ab}}$ & 0.001 & 0.006 \\
\hline $24 \mathrm{hpm}$ & $0.036^{\mathrm{b}}$ & $0.031^{\mathrm{a}}$ & $0.032^{a}$ & 0.001 & $<0.001$ \\
\hline \multicolumn{6}{|c|}{ Calpain-I (U/g) : Breed-type average } \\
\hline $1 \mathrm{hpm}$ & $1.074^{\mathrm{a}}$ & $1.197^{\mathrm{b}}$ & $1.204^{b}$ & 0.026 & $<0.001$ \\
\hline $24 \mathrm{hpm}$ & 0.759 & 0.776 & 0.748 & 0.029 & 0.780 \\
\hline \multicolumn{6}{|c|}{ Calpain-II (U/g) : Breed-type average } \\
\hline $1 \mathrm{hpm}$ & 1.030 & 0.985 & 1.028 & 0.016 & 0.072 \\
\hline $24 \mathrm{hpm}$. & $1.003^{b}$ & $0.947^{a}$ & $0.982^{a b}$ & 0.014 & 0.020 \\
\hline \multicolumn{6}{|c|}{ Spesific calpain-I (U) : Breed-type average } \\
\hline $1 \mathrm{hpm}$ & $0.019^{\mathrm{a}}$ & $0.021^{\mathrm{b}}$ & $0.021^{b}$ & 0.0004 & $<0.001$ \\
\hline $24 \mathrm{hpm}$ & 0.015 & 0.015 & 0.014 & 0.001 & 0.681 \\
\hline \multicolumn{6}{|c|}{ Spesific Calpain-ii (U) : Breed-type average } \\
\hline $1 \mathrm{hpm}$ & 0.018 & 0.017 & 0.018 & 0.0003 & 0.142 \\
\hline $24 \mathrm{hpm}$ & $0.019^{b}$ & $0.018^{\mathrm{a}}$ & $0.019^{b}$ & 0.0002 & 0.004 \\
\hline \multicolumn{6}{|c|}{ Calpastatin/calpain-I: Breed-type average } \\
\hline $1 \mathrm{hpm}$ & $2.23^{\mathrm{b}}$ & $1.88^{\mathrm{a}}$ & $1.91^{\mathrm{a}}$ & 0.042 & $<0.001$ \\
\hline $24 \mathrm{hpm}$ & $2.66^{b}$ & $2.24^{\mathrm{a}}$ & $2.36^{\mathrm{a}}$ & 0.078 & $<0.001$ \\
\hline \multicolumn{6}{|c|}{ Calpastatin/i +ii-Calpains: Breed-type average } \\
\hline $1 \mathrm{hpm}$. & $1.12^{\mathrm{b}}$ & $1.02^{\mathrm{a}}$ & $1.01^{\mathrm{a}}$ & 0.017 & $<0.001$ \\
\hline $24 \mathrm{hpm}$. & $1.08^{\mathrm{b}}$ & $0.96^{\mathrm{a}}$ & $0.98^{\mathrm{a}}$ & 0.022 & $<0.001$ \\
\hline \multicolumn{6}{|c|}{ Sarcomere length $(\mathrm{SL})(\mu \mathrm{m})$ : average } \\
\hline $1 \mathrm{dpm}$ & $1.74^{\mathrm{b}}$ & $1.73^{\mathrm{ab}}$ & $1.70^{\mathrm{a}}$ & 0.011 & 0.016 \\
\hline \multicolumn{6}{|c|}{ Myofibril fragment length (MFL) $(\mu \mathrm{m})$ : } \\
\hline Breed-type average & $34.17^{\mathrm{C}}$ & $30.19^{\mathrm{a}}$ & $32.08^{\mathrm{b}}$ & 0.501 & $<0.001$ \\
\hline $1 \mathrm{dpm}$ & $40.81^{b}$ & $35.81^{a}$ & $37.80^{\mathrm{a}}$ & 0.839 & $<0.001$ \\
\hline $7 \mathrm{dpm}$ & $34.35^{\mathrm{c}}$ & $28.92^{\mathrm{a}}$ & $30.92^{\mathrm{b}}$ & 0.521 & $<0.001$ \\
\hline $14 \mathrm{dpm}$ & $27.36^{\mathrm{b}}$ & $25.82^{\mathrm{a}}$ & $27.52^{\mathrm{b}}$ & 0.445 & 0.013 \\
\hline \multicolumn{6}{|l|}{ Collagen characteristics } \\
\hline Soluble collagen $(\mathrm{mg} / \mathrm{g})$ & 0.120 & 0.203 & 0.234 & 0.011 & 0.053 \\
\hline Insoluble collagen $(\mathrm{mg} / \mathrm{g})$ & $1.50^{\mathrm{a}}$ & $1.63^{\mathrm{ab}}$ & $1.76^{\mathrm{b}}$ & 0.047 & $<0.001$ \\
\hline Total collagen $(\mathrm{mg} / \mathrm{g})$ & $1.70^{\mathrm{a}}$ & $1.83^{\mathrm{a}}$ & $2.00^{\mathrm{b}}$ & 0.056 & $<0.001$ \\
\hline Collagen solubility (\%) & 11.45 & 11.02 & 11.44 & 0.316 & 0.549 \\
\hline
\end{tabular}


The residue content of the meat as experienced by the trained panel (Table 2) corresponded with the actual chemical collagen measurements (Table 3 ) in terms of the age-feed groups (AF, AP, ABF, ABP and $\mathrm{BP}$ ), which also corresponded with the tenderness evaluations (WBS and sensory panel) - AF and ABF having less residue than $A P$ and $A B P$ but equalling $B P$. On the other hand the collagen solubility decreased as the age of the animal increased, i.e. $A F>A P=A B F>A B P>B P$. This is as expected because the older the animal, the less soluble the collagen (stronger) should be in agreement with research reported by Crosley et al. (1994). However, tenderness profiles do not correspond with the collagen solubility profiles. The dilution effect of intramuscular fat could explain why connective tissue characteristics did not influence the tenderness measured by means of the sensory panel and Warner Bratzler shear force. It is possible that intramuscular fat had a larger influence on the tenderness of meat rather than the age effect of connective tissue. Although it is expected that older animals should have higher collagen insolubility with resultant tougher meat, it is possible that tougher connective tissue only starts to play a role in C-age class carcasses.

The $\mathrm{Ng}$ had the most tender meat when produced from AB-age feedlot and B-age pasture production systems, showing that breeds may adapt differently to different production systems. Sarcomere lengths were significantly longer in the ABF group indicating more relaxed muscles and therefore more relaxed animals. The shorter MFL measured in the ABF and BP groups indicates more advantageous tenderising calpain proteinase characteristics. This corresponds with the higher calpain-I levels and lower calpastatin/calpain-I levels (calpastatin is the protein inhibitor group of the tenderising system).

Different from Phase 1, the $\mathrm{Sm}-\mathrm{X}$ animals produced the most tender meat compared to that of the $\mathrm{Br}-\mathrm{X}$ and $\mathrm{Ng}$, as should be expected from a Bos taurus breed ( $\mathrm{Sm}-\mathrm{X}$ in Phase 1 proofed to contain Bos indicus genetics) (Frylinck et al., 2009). This indicates the importance of controlled genetics because not all Sm-X had typical Bos taurus meat tenderness (Maybe the Simmentaler from Phase 1 was crossed with Indicus). Breeders should be made aware of the genetic consequences on all levels including meat quality characteristics. The Nguni produced the most tender meat when produced from AB-age feedlot and B-age pasture production systems showing that they adapt better to these production systems.

The breed effect on tenderness in Phase 2 is supported by the calpain proteolytic system results presented in Table 3. The calpastatin inhibitor was the highest in the $\mathrm{Br}-\mathrm{X}$ and $\mathrm{Ng}$ and the lowest in the $\mathrm{Sm}-\mathrm{X}$. On the other hand the calpain-I enzyme levels were the lowest in the $\mathrm{Br}-\mathrm{X}$ and the highest in the Sm$\mathrm{X}$ and $\mathrm{Ng}$. The calpastatin/calpain-I ratio was the highest in the $\mathrm{Br}-\mathrm{X}$ and lower in the $\mathrm{Sm}-\mathrm{X}$ and $\mathrm{Ng}$ (Table 5). Myofibril fragmentation, a measure of the affectivity of post mortem proteinase action complement the calpain system showing that the $\mathrm{Sm}-\mathrm{X}$ had shorter fragments on average compared to that of the $\mathrm{Ng}$ with the $\mathrm{Br}-\mathrm{X}$ the longest (Br-X ageing slower than the other crossbreeds) (Table 5). On the breed level the genetic expression of the calpain system plays an important role towards the ultimate tenderness of the meat but not connective tissue characteristics.

Judging eating quality on the grounds of age alone is not reliable, because carcasses from older animals were not necessarily tougher than those of younger animals. The South African classification system and resultant remuneration should be revisited and consumers should be educated accordingly. Production systems should be optimised by using ideal pre- and post-slaughter conditions and adapted to accommodate different breed-types.

\section{Conclusion}

Careful consideration should be given to deciding on which pre- or post-slaughter treatment procedures to implement. The feed withdrawal period did not significantly affect the calpain proteolytic ageing system and resultant meat tenderness. On the other hand stress and low muscle energy levels in the animals post mortem because of the 24 hours pre-slaughter feed withdrawal lead to a higher incidence of DFD meat. Electrical stimulation was beneficial for LL tenderness even after 14 days of ageing compared to non-stimulated LL. Electrical stimulation had a greater advantage when the LL had a high inherent toughness and when animals were moderately stressed due to the 24 hour feed withdrawal period. Stimulation for 15 seconds and 120 seconds had equally favourable effects on tenderness, but the longer stimulation had a detrimental effect on drip loss and water holding capacity. The pasture animals needed more time to fully adapt to their environment and therefore reached a good condition only at an older age (B-age class). These results will probably vary depending on the condition of the pasture. Animals with $3-6$ permanent incisors do not necessarily produce tougher meat than that of $0-2$ permanent incisors. Some breeds such as the indigenous Nguni, produced more tender meat when raised on pasture or in the feedlot up to an older age. Although pasture animals produced tougher meat than feedlot animals, the meat became more tender at the older B-age class. Genetic expressed calpain proteolytic tenderising system plays a pivotal role in determining the ultimate meat tenderness. Although connective tissue becomes less soluble in the older animals it did not play an important role in determining tenderness in the age groups $A, A B$ and $B$. The experimental conditions in this specific project seemed to indicate towards percentage intra muscular fat (i.e. marbling) playing an important role in the 
tenderness outcome of the age-feed groups and therefore the fat condition of the animal at slaughter. Nguni animals seemed to marble well at the $A B$ age group that gave it the competitive edge in this specific production group. These findings show that the Red Meat Classification System should not be based on only a few research studies. The phenomenon of sarcopenia and the role of the calpain system on tenderness of meat produced from older animals should be further studied.

\section{Acknowledgements}

We thank Jocelyn Anderson and Hanlie Snyman of the Agricultural Research Council (ARC)-Animal Production Institute (API) for their assistance in sample analyses. We thank the ARC-Feedlot and Abattoir personnel for assistance in the rearing and processing of experimental animals and carcasses. We acknowledge Agricultural Research Council, Red Meat Research and Development South Africa, and Meat Industry Trust for facilities and financial support. This work is also based on the research supported in part by the National Research Foundation of South Africa (UID 75120).

\section{References}

Acocks, J.H.P., 1988. Veld types of South Africa. ( $3^{\text {rd }}$ ed.). Memoirs of the Botanical Survey of South Africa, No 57. pp. 1-146.

AGROMET, 1994. Agromet database. Pretoria: ARC-Institute for Soil, Climate and Water.

AMSA, 1995. Research guidelines for cookery, sensory evaluation and instrumental tenderness of fresh meat. Chicago, IL: American Meat Science Association, National Live Stock and Meat Board.

Anon., 9 Junie 2000. Vraag na AB-graad beesvleis nog te beperk. Landbouweekblad 62.

AOAC, 1985. Official Methods of Analyses $\left(14^{\text {th }}\right.$ ed.). Association of Official Analytical Chemists, Washington, D.C.

Bendall, J.R., 1972. In Meat Chilling - why and how? Meat Research Institute, Langford, Bristol, UK.

Bergman, I. \& Loxley, R., 1963. Two improved and simplified methods for the spectrophotometric determinations of hydroxyproline. Anal. Chem. 35, 1967-1970.

Cornall, A.G., Bardawill, G.J. \& David, M.M., 1949. Determination of serum proteins by means of the biuret reaction. J. Biol. Chem. 177, 751-766.

Crosley, R.I., Naude, R.T., Heinze, P.H. \& de Bruyn, J.F., 1994. Age classification of beef - A tender topic? Rooivleis 9-22.

Cross H.R., Carpenter, Z.L. \& Smith, G.C., 1973. Effect of intramuscular collagen and elastin on bovine muscle tenderness. J. Food Sci. 38, 998-1003.

Crouse, J.D., Cundiff, L.V., Koch, R.M., Koohmaraie, M. \& Seideman, S.C., 1989. Comparisons of Bos indicus and Bos taurus inheritance for carcass beef characteristics and meat palatability. J. Anim. Sci. 67, 2661-2668.

Culler, R.D., Parrish, F.C., Smith, G.C. \& Cross, H.R., 1978. Relationship of myofibril fragmentation index to certain chemical, physical and sensory characteristics of bovine longissimus muscle. J. Food Sci. 43, 1177-1180.

De Bruyn, J.F., 1991. Production and product characteristics of different cattle genotypes under feedlot conditions. DSc.-thesis, University of Pretoria, Pretoria, South Africa.

Dransfield, E. 1995. Control of meat texture at an industrial scale. Expression of Tissue Proteinases and Regulation of Protein Degradation as Related to Meat Quality. Eds: Ouali, A., Demeyer, D.J. \& Smulders, F.J.M., ECCEAMST. pp. 463-482.

Dransfield, E., 1996. Calpains from thaw rigor muscle. Meat Sci. 43, 311-320.

Dransfield, E., 1999. Meat tenderness - The calpain-I hypothesis. Proc. $45^{\text {th }}$ ICoMST Yokohama, Japan 4L2, 220.

Dreyer, J.H., Van Rensburg, A.J.J., Naudé, R.T., Gouws, P.J. \& Stiemie, S., 1979. The effect of chilling temperatures and mode of suspension of beef carcasses on sarcomere length and meat tenderness. S. Afr. J. Anim. Sci. 9, 1-9.

Faulkner, J.A., Larkin, L.M., Claflin, D.R. \& Brooks, S.V., 2007. Age-related changes in the structure and function of skeletal muscles. (Review). Clin. Exp. Pharmacol. P. 34, 1091-1096.

Ferguson, D.M., Jiang, S-T., Hearnshaw, H., Rymill, S.R. \& Thompson, J.M., 2000. Effect of electrical stimulation on protease activity and tenderness of $M$. longissimus from cattle with different proportions of Bos indicus content. Meat Sci. 55, 265-272.

Frylinck, L., 2001. Guaranteeing meat tenderness - a research priority for South Africa. Meat Industry Summit 2001. Holiday Inn, Johannesburg International Airport.

Frylinck, L. \& Heinze, P.H., 2003. Evaluation of meat tenderness of indigenous South African and other beef breeds. In Consistency of quality. Proc. $11^{\text {th }}$ International meat symposium. 29-30 January 2003, Centurion, South Africa. pp. 3-13. 
Frylinck, L., Van Wyk, G.L., Smith, T.P.L., Strydom, P.E., Van Marle-Köster, E., Webb, E.C., Koohmaraie, M. \& Smith, M.F., 2009. Evaluation of biochemical parameters and genetic markers for association with meat tenderness in South African feedlot cattle. Meat Sci. 83, 657-665.

Geesink, G.H. \& Koohmaraie, M., 1999. A rapid method for quantification of calpain and calpastatin activities in muscle. J. Anim. Sci. 77, 3225-3229.

GenStat., 2003. For Windows (7th ed.). In Introduction. Ed: Payne, R.W., Published 2003 by VSN International, ISBN 1-904375-08-1.

Goll, D.E., Boehm, M.L., Geesink, G.H. \& Thompson, V.F., 1997. What causes post mortem tenderization? Proc. $50^{\text {th }}$ Ann. Rec. Meat Conf. 50-60.

Government Notice No. 1548 of 16 October 1936. Grading of agricultural produce on Johannesburg. Government Gazette of the Union of South Africa. 106 (2385) 1-12.

Government Notice No. R.342 of 19 March 1999. Regulations regarding the classification and marking of meat. Government Gazette of the Republic of South Africa, 19 March 1999.

Hegarty, P.V.J. \& Naudé, R.T., 1970. The accuracy of measurement of individual skeletal muscle fibers separated by a rapid technique. Laboratory Practice 19, 161-163.

Heinze, P.H. \& Bruggemann, D., 1994. Ageing of beef: Influence of two ageing methods on sensory properties and myofibrillar proteins. Sci. Aliment. 14, 387-391.

Hill, F., 1966. The solubility of intramuscular collagen on meat animals of various age. J. Food Sci. 31, 161-166.

Ho, C.-Y., Stromer, M.H. \& Robson, R.M., 1996. Effect of electrical stimulation on post mortem titin, nebulin, desmin, and troponin-T and ultrastructural changes in bovine longissimus muscle. J. Anim. Sci. 74, 1563 - 1575.

Instron, 1990. Instron Series IX automated materials testing system. Version 5. Instron Corporation.

Koohmaraie, M., 1992. The role of the $\mathrm{Ca}^{2+}$-dependent proteases (calpains) in post mortem proteolysis and meat tenderness. Biochimie 74, 239-245.

Koohmaraie, M., 1996. Biochemical factors regulating the toughening and tenderization processes of meat. Meat Sci. 43, 5193-5201.

Ouali, A., 1990. Meat tenderization: possible causes and mechanisms. J. Muscle Foods 1, 129-165.

Ouali, A. 1991. Sensory quality of meat as affected by muscle biochemistry and modern technologies. In: Animal Biotechnology and the Quality of Meat Production. Eds: Fiems, L.O., Cottyn, B.G. \& Demeyer, D.I., Elsevier Science Publishers B.V., Amsterdam. pp. 85-105.

Owens, F.N. \& Gardner, B.A., 1999. Ruminant nutrition and meat quality. Proc. Recip. Meat Conf. 52, 25-36.

Pearson, A.M. \& Young, R.B., 1989. Muscle and Meat Biochemistry. San Diego: Academic Press, USA.

Purslow, P.P., 1999. The intramuscular connective tissue matrix and cell/matrix interactions in relation to meat toughness. Proc. 45 ${ }^{\text {th }}$ ICoMST. Yokohama, Japan. 4-L1, $210-219$.

Rutherford, M.C. \& Westfall, R.H., 1994. Biomes of Southern Africa: An objective categorization. Memoirs of the Botanical Survey of South Africa. 63, 1-94.

Schaefer, A.L., Jones, S.D.M. \& Stanley, R.W., 1997. The use of electrolyte solutions for reducing transport stress. J. Anim. Sci. 75, 258-265.

Shackelford, S.D., Wheeler, Y.L. \& Koohmaraie, M., 1995. Relationship between shear force and trained sensory panel tenderness ratings of 10 major muscles from Bos indicus and Bos taurus cattle. J. Anim. Sci. 73, 3333-3340.

Snedecor, G.W. \& Cochran, W.G., 1980. Statistical Methods. Iowa State University Press, USA.

Strydom, P.E., Naudé, R.T., Smith, M.F., Scholtz, M.M. \& van Wyk, J.B., 2000. Characterisation of indigenous African cattle breeds in relation to meat quality traits. Meat Sci. 55, 79-88.

Strydom, P.E., Burrouws, H., Frylinck, L. \& Van der Westhuizen, J., 2008. Feed efficiency, carcass and beef quality of steers from communal, emerging and commercial farmer herds in South Africa. Aust. J. Exp. Agr. 48, 599-607.

Strydom, P.E., Frylinck, L., Montgomery, J.L. \& Smith, M.F., 2009. The comparison of three b-agonists for growth performance, carcass characteristics and meat quality of feedlot cattle. Meat Sci. 81, 557-564.

Thompson, J., 2002. Managing meat tenderness. Meat Sci. 62, 295-308.

Warkup, C., Marie, S. \& Harrington, G., 1995. Consumer perceptions of texture; the most important quality attribute of meat? In: Expression of Tissue Proteinases and Regulation of Protein Degradation as Related to Meat Quality. Eds: Ouali, A., Demeyer, D.J. \& Smulders, F.J.M., ECCEAMST. pp. 225-237.

Whipple, G., Koohmaraie, M., Dikeman, M.E., Crouse, J.D., Hunt, M.C. \& Klemm, R.D., 1990. Evaluation of attributes that affect longissimus muscle tenderness in Bos taurus and Bos indicus cattle. J. Anim. Sci. $68,2716-2728$. 